\title{
Effects of chromium supplementation on early lactation performance of Holstein cows
}

\author{
WZ Yang, A Subiyatno, DN Mowat \\ University of Guelph, Guelph, ON N1G 2W1, Canada
}

Recently, chromium $(\mathrm{Cr})$ supplementation has been found to improve weight gain and reduce morbidity in newly arrived stressed feeder calves (Mowat et al, 1993, Can J Anim Aci, 73, 49-55). This study was to investigate the effects of $\mathrm{Cr}$ supplementation on early lactation of cows.

Two experiments were conducted in two consecutive years using a total of 74 Holstein cows, 12 primiparous (PP) and 22 multiparous (MP) in experiment I, and $18 \mathrm{PP}$ and $22 \mathrm{MP}$ in experiment II. Cows were randomly assigned to two treatments including control and $0.5 \mathrm{ppm}$ supplemental chelated $\mathrm{Cr}$ (Metalosate, $3.52 \% \mathrm{Cr}$, Sureleen-Albion Agra Inc, Arva, ON). All cows were fed ad libitum total mixed rations. Duration of experiment for each cow was 22 wk (from wk 6 prepartum to wk 16 postpartum). Daily feed intake and milk yield were recorded. Milk samples were collected weekly for milk component analysis. Blood samples were taken via the coccygeal vein at every two wk. Serum NEFA and BHBA were determined using NEFA C Kit and BHBA $\mathrm{Kit}$, respectively. Data were analyzed by general linear model procedure of SAS (1985) with main effects : calving season, parity, $\mathrm{Cr}$ and week postpartum (split plot within main treatments) and all interactions. For analysis of blood metabolites, data obtained at wk 6 prepartum were used as covariate.

Supplemental $\mathrm{Cr}$ increased milk yields in PP cows by $9 \%(P<0.05)$ during first 16 wk of lactation. The greatest difference tended to occur during the first 8 wh of lactation. However, in MP cows milk yields were not affected by $\mathrm{Cr}$ supplementation. Dry matter intake and milk components were not affected by supplemental $\mathrm{Cr}$ except milk lactose in MP cows which was reduced $(\mathrm{P}<0.05)$ by $\mathrm{Cr}$ supplementation. In addition, both serum NEFA and BHBA concentrations were reduced $(P<0.05)$ by $\mathrm{Cr}$ supplementation for parity 3 and 4 cows.

Chromium requirements are well-known to increase during periods of stress including late pregnancy and early lactation (Anderson, 1994, Proc Alltech's Tenth Ann Symp). Subiyatno et al (1993, Proc ADSA Ann Mtg) showed that PP cows, in particularly, appeared to be deficient in $\mathrm{Cr}$ during the late pregnancy and early lactation as judged by glucose tolerance tests. The increased milk production may be explained by increased gluconeogenesis which was suggested during propionate loading tests in early lactating PP cows fed supplemental $\mathrm{Cr}$ (Yang and Mowat, 1994, Proc ADSA/ASAS Ann Mtg).

In conclusion, supplemental $\mathrm{Cr}$ increased milk yield during early lactation in PP cows and may reduce serum BHBA levels or subclinical ketosis in aged MP cows. Supplemental $\mathrm{Cr}$ appears to be required more for PP than for MP cows during early lactation.

\begin{tabular}{|c|c|c|c|c|c|c|}
\hline \multirow[t]{3}{*}{ - } & \multirow{2}{*}{\multicolumn{3}{|c|}{ Primiparous }} & \multirow{2}{*}{\multicolumn{3}{|c|}{ Multiparous }} \\
\hline & & & & & & \\
\hline & $-\mathrm{Cr}$ & $+\mathrm{Cr}$ & SEM & $-\mathrm{Cr}$ & $+\mathrm{Cr}$ & SEM \\
\hline DMI (kg/d) & 16.4 & 16.8 & 0.70 & 21.1 & 21.1 & 0.53 \\
\hline Milk $(\mathrm{kg} / \mathrm{d})$ & $24.3^{\mathrm{b}}$ & $26.5^{\mathrm{a}}$ & 0.73 & 36.7 & 36.5 & 0.59 \\
\hline Milk fat $(\%)$ & 3.85 & 3.84 & 0.15 & 3.56 & 3.70 & 0.14 \\
\hline Milk protein (\%) & 3.11 & 3.13 & 0.07 & 3.06 & 3.04 & 0.06 \\
\hline Milk lactose (\%) & 4.85 & 4.98 & 0.05 & $4.89^{a}$ & $4.78^{\mathrm{b}}$ & 0.04 \\
\hline
\end{tabular}

SEM : Standard error of the mean

$a, b$ : Means in the same row within the same cows with different superscripts differ $(P<0.05)$ 